\title{
Reflexões teóricas sobre Ensino de Ciências e Cinema: aproximações possíveis com a linguagem cinematográfica
}

Rodrigo Vasconcelos Machado de Mello

rodrigo-vmm@hotmail.com

0000-0002-8167-2962

Universidade Federal do Rio de Janeiro - Brasil

Waldmir Nascimento de Araujo Neto

waldmir@iq.ufri.br 0000-0003-0896-4026

Universidade Federal do Rio de Janeiro - Brasil

\begin{abstract}
RESUMO
O cinema pode ser uma ferramenta com potencial de promoção da cultura pessoal do estudante em cultura escolar. Para tanto, o professor adquire papel chave, assumindo papel mediador. No entanto falta à este apropriar-se do cinema como uma manifestação artística e técnica, portadora de uma linguagem peculiar. No Ensino de Ciências em particular, falta uma aproximação com conhecimentos da área de cinema que viabilizariam um olhar mais crítico sob a ciência no cinema. Nossas intenções residem em estabelecer uma aproximação com este quadro teórico, especialmente a teoria de linguagem cinematográfica de Marcel Martin que pressupõe uma tensão dialética entre espectador e filme. Encontramos neste conceito confluência com a teoria de mediação semiótica de Vigotski, possibilitando diálogos entre estas. Esta abordagem teórica aponta para caminhos pouco explorados pela pesquisa de Ensino de Ciência, possibilitando uma discussão em sala de aula de uma ciência mais humana e menos dura.
\end{abstract}

PALAVRAS-CHAVE: Ensino de ciências. Cinema. Linguagem cinematográfica. Mediação semiótica. Vigotski. 


\title{
O CINEMA E SEU POTENCIAL PEDAGÓGICO
}

Não é de hoje que a Escola busca se apropriar do cinema como ferramenta pedagógica. Relatos do início do século XX demonstram a preocupação por partes de professores e pesquisadores em otimizar o uso destes recursos para fins educacionais (Dransfield, 1927 e Angell, 1929).

A concepção que temos hoje é que o cinema em sala de aula pode ser um catalisador, estimulando e inspirando os estudantes a ampliarem sua bagagem cultural, amadurecendo uma visão crítica de parte das informações que nos chegam. Além disso, constitui uma oportunidade da Escola dialogar com o repertório cultural de seus estudantes. Adotamos aqui como um pressuposto teórico a discussão proposta por Georges Snyders (1988) em sua obra A alegria na Escola, onde o conjunto prévio de cultura e valores do estudante, adquiridos em sua família e comunidade, podem estabelecer um vínculo com a cultura escolar, de maneira dialética. Para Snyders, haveria dois tipos de cultura: a cultura primeira, não sistematizada e adquirida no cotidiano do individuo, e a cultura elaborada, ou escolar, que é sistematizada (SNYDERS, 1988).

Roberto Muniz Barretto de Carvalho (1999), em sua análise da obra de Snyders, salienta a relação entre a cultura primeira e cultura elaborada e como seu aspecto dialética pode conduzir a uma compreensão ampliada acerca das coisas e seus estados no mundo.

\begin{abstract}
Snyders procura demonstrar que entre as duas formas de cultura não existem antagonismos; existem diferenças, mas estas não criam entre as duas um fosso intransponível. Pelo contrário, de uma forma dialética, a cultura escolar, representada pelo professor, encontra-se em continuidade com a cultura primeira, que é a cultura do aluno. Do mesmo modo, entretanto, existe também uma ruptura entre elas, já que a cultura elaborada operou uma crítica sobre a cultura primeira, organizou e sistematizou seus dados o que possibilita uma nova visão da realidade (Carvalho, 1999, p. 163).
\end{abstract}

Esse processo de diálogo entre culturas não ocorre sem a mediação do professor, que estabelece a ponte entre a cultura primeira e a cultura escolar, por meio da sistematização do conhecimento. Percebe-se, portanto, que a presença do professor neste processo se faz crucial.

No que tange o uso do cinema em processos de escolarização, a cultura primeira constitui a ignição que desperta a curiosidade e interesse do estudante. É o que estabelece vínculo entre este e a experiência em assistir o filme.

Luis Paulo de Carvalho Piassi (2013) defende que o cinema pode ser uma das ferramentas possíveis para estabelecer este diálogo:

Com isso queremos argumentar que não se trata de levar tais produtos para as salas de aula como forma de cativar os alunos e facilitar seu aprendizado. Os produtos já estão lá, na mente dos alunos, em seus cadernos, em seus aparelhos de música, em seu imaginário, em sua prática social (PIASSI, 2013 p. 250).

Portanto, as experiências e valores prévios dos estudantes, além da mediação do professor, são fatores essenciais no que toca o uso desta mídia no espaço escolar. 
Lamentavelmente, em algumas ocasiões, o potencial educativo do cinema se limita em sala de aula, adquirindo um papel meramente recreativo ou pior, com o objetivo de suprir a falta do professor. Nos dias atuais, onde a facilidade de acesso ao filme é extremamente comum, esta estratégia por muitas vezes não encanta o estudante. Afinal, "por que ver o filme na escola, se posso vê-lo em casa de maneira mais confortável na hora que eu preferir?" O cinema dessa maneira perde seu potencial pedagógico.

Além disto, o papel do professor é muitas vezes desconsiderado, como se o filme falasse por si só. Discordamos desta postura, o professor deve assumir papel chave neste processo. $O$ filme só alcança o seu real potencial pedagógico com a intervenção do professor, que previamente planejou a atividade, selecionou o filme para abordar determinado assunto e mais do que isto, seleciona dentro das riquezas de imagens fílmicas, aquelas em que os estudantes devem direcionar seu olhar, fazendo emergir aquilo que poderia passar despercebido pelo estudante se visse o filme em outras condições. O professor é, portanto, um mediador do processo.

Para tanto o professor deve estar preparado para agir como tal. O que não é observado de acordo com a literatura. Muito disto encontra-se na formação docente, uma vez que falta a este perceber o cinema como uma Tecnologia de Informação e Comunicação (TIC). Devendo, deste modo, conhecer um pouco mais a fundo algumas de suas características, como algumas de suas técnicas e recursos de linguagem particular. $\mathrm{O}$ conhecimento destas permite direcionar o olhar para alguns aspectos pensados pelo idealizador da obra.

Rogério Christofoletti (2009) em pesquisa com 55 professores do ensino superior de 11 cursos diferentes sobre o uso do cinema em suas aulas observou que mais da metade acredita ser desnecessário ter conhecimento sobre teorias de cinema (Christofoletti, 2009). Todavia, este não parece ser um problema apenas da educação brasileira. José Rodríguez Terceño (2014) cita que nas escolas espanholas, o cinema muitas vezes é usado para suprir a ausência do professor e que falta nos professores espanhóis a formação necessária para trabalhar o cinema como uma TIC (Terceño, 2014).

Esses dados ilustram, como de modo geral, o cinema não é explorado como atividade pedagógica com todo seu potencial. Muito desse problema reside na formação do professor. Neste ponto Vanessa Mendes Carrera (2012) destaca que

Para que o professor/mediador esteja preparado para estimular o aluno/espectador a assistir, selecionar informações e interpretar os filmes, é necessário que ele mesmo tenha tido oportunidade de estar no lugar do aprendiz durante seu curso de formação profissional assistindo, discutindo e avaliando filmes em ambiente acadêmico, exatamente como é feito com livros didáticos ou textos literários (CARRERA, 2012, p. 50).

No que se refere ao uso do cinema na Escola, na área do Ensino de Ciências, as lacunas são ainda maiores e nos oferece oportunidades de nos debruçarmos sob esta ferramenta de maneira diferenciada, expandindo nossa atuação.

\section{CINEMA E ENSINO DE CIÊNCIAS}


É surpreendente que na área do ensino de ciências tenhamos ainda poucos trabalhos no que tange o uso do cinema em sala de aula. Surpreende, pois cinema e ciência sempre flertaram. Surpreende por perceber o quanto da ciência é representada no cinema e ainda assim seu potencial se limita. Muitos são os motivos e dificuldades encontrados por professores neste sentido.

No caso específico do ensino de ciências, por meio do cinema, temos publicações na área, tais como os três volumes da coleção História da Ciência no Cinema (Oliveira, 2005; 2008; Figueiredo; Silveira, 2010), que reúnem artigos de historiadores e pesquisadores sobre tópicos da Biologia, Física, Medicina, Química, bem como aspectos biográficos de cientistas. Mais recentemente, a coleção adquiriu uma coletânea dos melhores artigos presentes nos três volumes intitulada Ciência e Cinema na Sala de Aula (Oliveira, 2012) que trazem como novidade roteiros de sugestões de atividades em sala de aula.

Apesar dessas iniciativas, parece haver alguns obstáculos encontrados por professores no que tange o emprego da ferramenta cinematográfica. Algumas revisões bibliográficas sugerem que o emprego de filmes para fins de educação em ciências é pequeno e recente, sendo uma minoria com discussões relacionadas à Ciência. Alguns obstáculos que parecem ser encontrados por professores de maneira geral e que tange também os profissionais da área de ciências são o despreparo para lidar com a linguagem audiovisual e o receio de lidar com erros conceituais presentes nos filmes. Deste modo, filmes comerciais, parecem sofrer de um preconceito por parte dos professores que em geral preferem vídeos educativos ou simulações. (Carrera, 2012).

De fato, visões errôneas da ciência, seus conceitos e estereótipos da figura do cientista são comuns na história do cinema. Na literatura encontramos análises de como o cinema tem reproduzido algumas destas visões limitadas e caricatas da prática científica e da figura do cientista (Cunha; Giordan, 2009), bem como estas representações variaram ao longo das décadas (Kosminsky; Giordan, 2002).

Independente de trazerem visões errôneas ou concordantes com a realidade, estas representações foram produzidas em um dado contexto histórico-cultural, não devendo ser simplesmente descartadas. A análise e reflexão destas representações se faz importante ao amadurecimento da imagética da ciência. Do mesmo modo que a ciência não se faz de maneira neutra, o cinema também não se faz. Marcos Napolitano (2013) explicita que

A peculiaridade do cinema é que ele, além de fazer parte do complexo da comunicação e da cultura de massa, também faz parte da indústria do lazer e (não nos esqueçamos) constitui ainda obra de arte e tecnicamente sofisticada. O professor não pode esquecer destas várias dimensões do cinema ao trabalhar filmes em atividades escolares (NAPOLITANO, 2013, p. 14).

Deste modo, ao optar por usar o cinema como ferramenta de ensino, o professor deve ter bem claro para si as implicações sociais, culturais, econômicas que envolvem o contexto de produção do filme e analisar seu discurso de maneira crítica, motivando esta mesma postura em seus estudantes. Daí a intenção de reforçarmos a necessidade do caráter mediador do professor em uma atividade com cinema na escola, estando o professor consciente e preparado para isto. 
Para termos uma adequada compreensão dos mecanismos de funcionamento do cinema, necessitamos saber que este possui uma linguagem própria, que permeia de sentidos diversos a narrativa cinematográfica, fazendo uso de um conjunto de técnicas. No entanto, esta linguagem peculiar do cinema, parece não ser explorada de maneira adequada na área do Ensino de Ciências.

Luiz Augusto Coimbra Rezende Filho e colaboradores (2011), através de levantamento bibliográfico em periódicos de Ensino de Ciências, detectaram a existência de 11 publicações entre os anos de 2000 e 2008, e perceberam que a área tem se "auto-referenciado" (REZENDE Filho; Pereira; Vairo, 2011 p.196) ao tratar do tema cinema e educação nos trabalhos publicados neste intervalo de tempo. Esses aspectos, conforme destacado pelos autores, evidenciam inclusive a falta de interdisciplinaridade entre a área de Educação em Ciências e o referencial teórico-metodológico da área audiovisual/comunicação. O que se alinha com o cenário geral quando se refere à cinema na escola.

Deste modo, temos atualmente na área de ensino de ciências um quadro que se apresenta limitado no que tange o uso do cinema na escola e por muitas vezes repetitivo. Nossas intenções residem em propor um quadro teórico que torna possível um diálogo entre a teoria do cinema, aqui representada por Marcel Martin, tendo como pano de fundo o conceito de mediação semiótica de Levi Vigotski.

\section{PROPOSTA TEÓRICA}

Tendo em vista a lacuna teórico-metodológica que a área de ensino de ciências possui (no que se refere ao uso do cinema em sala de aula) nossa proposta é que façamos uma aproximação com a área de cinema. Para tanto, nos apropriamos da linguagem cinematográfica, enquanto recurso técnico e estético. Pressupondo, com isso, que há uma tensão dialética que opera na Escola onde a cultura individual dos estudantes e a cultura escolar estão em constante diálogo.

Deste modo, propomos como aporte teórico o conceito de mediação semiótica de Lev Vigotski por conceber uma dinâmica dialética entre o indivíduo e a sua realidade. Nossa intenção é propor uma aproximação desta com a teoria do cinema, mais especificamente a teoria de linguagem cinematográfica de Marcel Martin, por reconhecer nesta um ponto de interseção com a teoria de mediação semiótica de Vigotki.

Com isso em mente, consideramos que o cinema pode ser uma ferramenta que tendo a mediação adequada do professor pode facilitar a relação entre estas manifestações culturais díspares. Para tanto o professor deve estar preparado, apropriando-se de alguns recursos e técnicas cinematográficas, tal como a sua linguagem.

A seguir, discutimos sobre estes referenciais teóricos e as possibilidades de diálogos estabelecidas entre estes. Acreditamos que estas contribuições teóricas ao ensino de ciências podem ampliar o debate e a pesquisa do uso do cinema em sala de aula, assumindo um caráter interdisciplinar em consonância com outras áreas do conhecimento, o que pode gerar um caráter teórico e metodológico inovador para a área. 


\section{MEDIAÇÃO SEMIÓTICA: OS SÍMBOLOS CONECTANDO O SER HUMANO E O MUNDO}

A fim de entendermos o conceito de mediação semiótica proposto por Vigotski, necessitamos reconhecer que seu trabalho está calcado na tradição do materialismo histórico (ciência marxista) e do materialismo dialético (filosofia marxista). Onde se entende que o ser humano opera de maneira dialética sobre a natureza, onde um exerce transformações sobre o outro (Joenk, 2002).

James Wertsch (1981) salienta que a psicologia soviética baseada na abordagem de Marx e Engels destaca a importância do sujeito ativo, cujo conhecimento da realidade material se baseia em suas interações com o mundo. Segundo esse autor, nenhum progresso pode ser esperado de uma psicologia baseada na ideia do ser humano passivo, um mero receptáculo de seu ambiente físico e social. Dentro desta concepção filosófica, apenas pela interação com o mundo material e com outros indivíduos pode-se desenvolver um conhecimento da realidade.

Este conceito foi discutido com maior profundidade por Alexei Leontiev (1981), um dos alunos de Vigotski mais recorrentes na literatura. De acordo com Leontiev, considerar apenas o mundo material ou o organismo humano não é suficiente para se compreender o desenvolvimento do conhecimento a respeito do mundo. Para tal compreensão, se faz necessário o conceito de atividade, onde o ser humano se engaja nesse processo. Esse conceito tornou-se central na psicologia soviética e é uma extensão direta das ideias de Marx e Engels (Leont'ev, 1981).

Basicamente, dentro deste quadro teórico, a atividade humana pode ser de dois tipos: instrumental e semiótica. A atividade instrumental é mediada pelo uso de instrumentos, criados com determinada intenção de ação do homem sobre sua realidade material. Por sua vez, a atividade semiótica consiste em sistemas de signos criados para representar a realidade e tornar possível a comunicação entre os membros de um grupo, tornando o real cognoscível e comunicável. 0 caráter dialético das atividades humanas mediadas permite que as interações indivíduo-natureza resultem em produções culturais, o que coloca o ser humano acima da ordem biológica (Pino, 1995).

Neste sentido, a apropriação do conhecimento pelo ser humano se da de maneira singular, sendo uma resignificação de algo já culturalmente significado. Como Pino sintetiza: "é a resignificação pelo sujeito de algo já significado socialmente, o que pressupõe uma atividade semiótica específica a cada sujeito" (ibidem, 1995, p. 33). Portanto, temos um caráter subjetivo fortemente influente nesta relação.

Os fundamentos deste processo residem na perspectiva da corrente histórico-cultural da psicologia, na qual Vigotski contribuiu em sua breve carreira. Na obra A Formação Social da Mente (2007), Vigotski apresenta o conceito de mediação semiótica, desenvolvido com seus colegas baseados em dados experimentais com indivíduos, sobretudo crianças.

Dada a dinâmica dialética da mediação semiótica, os conceitos de signo e instrumentos podem ser tratados de maneira análoga, dadas as suas funções mediadoras. Suas diferenças repousam no fato de o instrumento ser uma maneira do ser humano exercer influência sobre o objeto (é orientado 
externamente), enquanto o signo é uma forma de controle do próprio individuo (sendo orientado internamente).

Estas operações com signos são estruturadas na dinâmica estímulo-resposta, que o autor representa pela fórmula $S \rightarrow R$, o signo, caracteriza-se por um elo intermediário, um estímulo de segunda ordem que é "colocado" no interior da operação. O termo "colocado" é destacado por Vigotski, salientando que "o indivíduo deve estar ativamente engajado no estabelecimento desse elo. Esse signo possui, também, a característica importante de ação reversa (isto é, ele age sobre o indivíduo e não sobre o ambiente)" (VIGOTSKI, 2007, p. 33).

Neste ponto chegamos a um caráter importante da mediação semiótica que é sua propriedade dialética. Ou seja, da mesma forma que o signo permite que o ser humano atue sobre a realidade, modificando-a, o inverso também é possível, o signo constantemente modifica as operações psicológicas do individuo. Como Vigotski salienta, "o uso dos signos conduz os seres humanos a uma estrutura específica de comportamento que se destaca do desenvolvimento biológico e cria novas formas de processos psicológicos enraizados na cultura" (ibidem, 2007, p. 34).

Nesta perspectiva, o desenvolvimento psicológico do individuo não é fruto de um conjunto de conhecimentos internos ou externos, mas sim estabelecido por meio de um processo dialético, onde o seio cultural em que se encontra o individuo é influente e influenciado.

\section{A IMAGEM CINEMATOGRÁFICA E SEU CARÁTER DIALÉTICO}

O conceito de mediação semiótica proposto por Vigotski encontra confluências com a teoria de cinema de Marcel Martin, uma vez que para este último a imagem cinematográfica se relaciona dialeticamente com o espectador.

Marcel Martin é constantemente citado por seu livro A Linguagem Cinematográfica (MARTIN, 1963), publicada originalmente em 1955. A obra oferece uma acessível introdução ao modo de se fazer e assistir filmes. Além disto, estabelece de maneira bem clara o cinema não unicamente como um produto de consumo, mas como a manifestação de arte que mais se aproxima do real. De origem francesa e crítico de cinema, Martin oferece nessa obra uma leitura primordial para se desenvolver uma visão mais profunda desta manifestação de arte.

O conceito central da obra de Martin é a ideia de que a imagem é essencial ao cinema, sendo "a matéria-prima fílmica" (MARTIN, 1963, p. 17). Esta imagem é um fragmento estático e inerte da realidade, além disto, está sujeita ao sentido desejado pelo seu realizador, o que provoca em seu público uma relação dialética. $\mathrm{O}$ autor define seis características fundamentais e específicas da imagem, à saber: a imagem é realista, está sempre "no presente", constitui uma "realidade artística", possui "papel significante", possuí caráter de "unicidade representativa" e "plasticidade".

Dessas características da imagem a que mais nos interessa, é a sua plasticidade. Essa peculiaridade da imagem, segundo Martin, corresponde a imagem em si, na materialidade do que mostra, não podendo ser equívoca ou ambígua. A imagem encontra-se inserida em um dado contexto, sendo a relação 
com o meio determinante em seu sentido. $\mathrm{O}$ autor destaca que este contexto pode ser fílmico, onde "a imagem está integrada em uma sequência temporal e esta coexistência desvia seu significado de um modo determinado" (ibidem, 1963 , p. 26). Há ainda o contexto mental do espectador, que depende da bagagem deste e tange seu gosto, instrução, cultura, opiniões morais, políticas e sociais, preconceitos e ignorância. Temos então que uma mesma imagem fílmica pode ser percebida de diferentes modos por diferentes espectadores.

Em síntese, a imagem é plástica, uma vez que representa de maneira unívoca a realidade e maleável ao adquirir um sentido, quando em contato com as demais imagens selecionadas pelo idealizador da obra, abrindo margem para interpretações variadas. A imagem fílmica, portanto estabelece uma inter-relação dialética com o espectador e graças ao seu caráter plástico o promove a um sujeito ativo durante a experiência fílmica.

Esta visão de um espectador ativo alinha-se com a ideia proposta por Rosália Duarte em sua obra Cinema e Educação (Duarte, 2009) onde defende que o expectador de cinema é embebido de uma "competência para ver" (ibidem, 2009 , p. 13) que não é proporcionada apenas com o costume de assistir filmes, mas sim com a "atmosfera cultural" em que se encontra. Duarte defende que o contexto cultural em que se encontra o individuo, o que para Martin equivale ao contexto mental da imagem (ou o que Snyders chamaria de cultura primeira), permite desenvolver maneiras de se relacionar com a cultura, incluindo o cinema, podendo levar a uma disposição a se sentir envolvido pela linguagem cinematográfica. Deste modo, dependendo do grupo social a que pertence um individuo, diferentes camadas de interpretação podem surgir em uma dada obra cinematográfica.

Esta visão promove o espectador de um mero sujeito passivo, receptor de imagens e sons, a um individuo ativo que se relaciona dialeticamente com a obra cinematográfica. Esta riqueza de sentidos que afloram da tensão dialética espectador-obra é possível graças à expressividade da imagem. Segundo Martin, esta expressividade só é possível graças a alguns fatores: em primeiro lugar, o papel da câmera (movimentos do aparelho, diversos tipos de ângulos e enquadramentos). Em segundo lugar, o plano, iluminação, os décors (cenário e objetos pertencentes à este) e figurino. A forma como a imagem é gravada e consequentemente percebida pelo espectador pode colaborar para a construção de um sentido da imagem. Estando a câmera em movimento, em repouso ou com diferentes graus de inclinação em relação ao objeto filmado, podemos perceber sugestões de valores que acrescem sentidos à imagem registrada.

\section{LINGUAGEM CINEMATOGRÁFICA SEGUNDO MARCEL MARTIN}

Segundo Marcel Martin (1963), são sugeridos sentidos à imagem por meio da forma como esta é registrada. Neste sentido, o idealizador da obra tem papel crucial. O simples movimento de câmera, de acordo com os seus variados tipos, pode conferir determinados sentidos. Deste modo, Martin define três modalidades de movimentos de câmera: o travelling, a panorâmica e a trajetória.

O travelling consiste no deslocamento da câmera, para frente ou para trás, deslocamento. A segunda categoria seria a panorâmica, que consiste na rotação 
desta em torno de seu eixo vertical ou horizontal sem deslocamento do aparelho. Por fim, a trajetória, combina o travelling e a panorâmica com auxílio de uma grua, em muitos casos este recurso destina-se a introduzir o espectador no universo diagético da obra. De modo geral, estes movimentos podem assumir funções descritivas ou dramáticas, dependendo da intenção dos idealizadores da obra.

Exemplificando, temos como emprego do movimento de câmera com cunho descritivo um travelling para frente ou para trás, onde a câmera acompanha um personagem ou objeto em movimento. Ou ainda a descrição de um espaço ou de uma ação, onde o movimento de câmera pode nos apresentar um ambiente ou cenário importante na trama. Tratando-se de questões dramáticas, podemos ter, por exemplo, a expressão de tensão mental de um personagem. Deste modo, ao movimentar-se, a câmera se aproxima do rosto do personagem, evidenciando seu interior, seus sentimentos. A expressão assumida pelo ator reforça os sentidos pretendidos.

Outro recurso comum é a distância entre a câmera e o sujeito, que configura o plano. Dentro das classificações de Martin, temos o primeiro plano e o plano geral por possuírem na maioria das vezes, um significado psicológico preciso. 0 plano geral nas palavras de Martin, "reintegra o homem no mundo, faz dele presa das coisas, o 'objetivo'; daí uma tonalidade psicológica muito pessimista, uma ambiência moral antes de tudo negativa" (Martin, 1963, p. 42). Por sua vez, o primeiro plano, é um olhar mais próximo aos personagens, é uma forma de sondar seus pensamentos e sentimentos, como o autor cita, é a "mais válida tentativa de cinema interior" (ibidem, 1963, p. 42). Esta categoria inclui também o primeiríssimo plano, onde a câmera se posiciona ainda mais próxima ao objeto, nos oferecendo uma óptica mais detalhada. Neste caso, podemos visualizar uma parte específica de um objeto ou do corpo de um personagem, podendo carregar uma intensa função dramática.

Os ângulos de câmera também podem conferir significados psicológicos. Quando a câmera foca o individuo de cima para baixo, temos o plongée, que em geral, produz um efeito que tende a minimizar o individuo, "esmagá-lo moralmente, abaixando-o ao nível do solo, fazendo dele um joguete da fatalidade" (MARTIN, 1963, p.44). Por outro lado, no contre-plongée, onde o sujeito é focado de baixo para cima, tende a assumir como efeito uma impressão de superioridade, "de exaltação e de triunfo, pois engrandece os indivíduos e tende a enaltecê-los, destacando-os assim sobre o céu até aureolá-los de nuvem negra" (ibidem, p.44). Por sua vez o enquadramento inclinado, pode conferir uma representação, ao materializar ao espectador uma impressão sentida por um personagem, tal como, uma preocupação ou um desequilíbrio moral. Tal função é adquirida quando a câmera pode assumir diferentes graus de inclinação em relação ao objeto filmado. Finalmente no enquadramento desordenado, a câmera é sacudida em todos os sentidos, podendo conferir de modo subjetivo o ponto de vista de um indivíduo em movimento ou de modo objetivo uma ideia mais ampla de caos, tumulto.

O enquadramento talvez seja o recurso mais sutil e, portanto com maior valor dramático conferido à imagem fílmica. Trata-se da composição da imagem, como os objetos e sujeitos estão organizados perante a câmera de modo a construir determinado significado. Isto dependerá de como o idealizador do filme irá organizar tais elementos diante da objetiva e posteriormente, como estes 
serão observados em tela. Não há um padrão neste caso, sendo, portanto um elemento que confere certa poética à imagem fílmica.

Do mesmo modo que o enquadramento, a iluminação pode ser dotada de uma dada poética, de acordo com o idealizador da obra. De maneira geral, a iluminação escolhida durante a produção do filme produz luz e sombras que podem gerar significados de contraste, dualidade e conflito. A tensão entre o bem e o mal, por exemplo, é um sentido recorrente.

Além do papel criador de sentidos da imagem, Martin salienta o valor dado pela combinação destas, conhecida como montagem. A montagem é fundamental na linguagem cinematográfica, sendo impossível falar de cinema sem cita-la. De acordo com a definição do autor, "montagem é a organização dos planos de um filme em certas condições de ordem e de tempo" (MARTIN, 1963, p. 112). A montagem se da pela união de dois ou mais planos, cujo autor define como sendo "uma unidade elementar de ponto de vista" (ibidem, p. 112). Tecnicamente, o plano corresponde ao intervalo entre dois cortes.

O papel criador da montagem se faz compreendido pela experiência de Kulechov, onde um plano com a imagem do rosto indiferente de um ator pode ser interpretada expressando diferentes sentimentos. Fome, sofrimento pela perda e desejo, podem ser sentidos no rosto do individuo, dependendo da imagem precedente, no caso, um prato de comida, uma criança em um caixão e uma mulher em um divã. Esta é uma amostra de como a montagem pode ser uma ferramenta poderosa para direcionar a interpretação e os sentimentos sugeridos ao espectador.

A eficiência da montagem pode ser entendida pelo fato de podermos construir mentalmente uma visão global do que vimos de modo que a sucessão dos planos nos pareça natural, onde os cortes passam despercebidos. Uma boa montagem nos oferecerá uma representação do conjunto que nos dá a ilusão da percepção do real.

Na Figura 1 a seguir apresentamos um resumo dos principais recursos de linguagem cinematográfica propostas por Marcel Martin e que consideramos pertinentes para um olhar diferenciado do cinema na Escola. 
Figura 1. Principais recursos de linguagem cinematográfica, segundo Marcel Martin

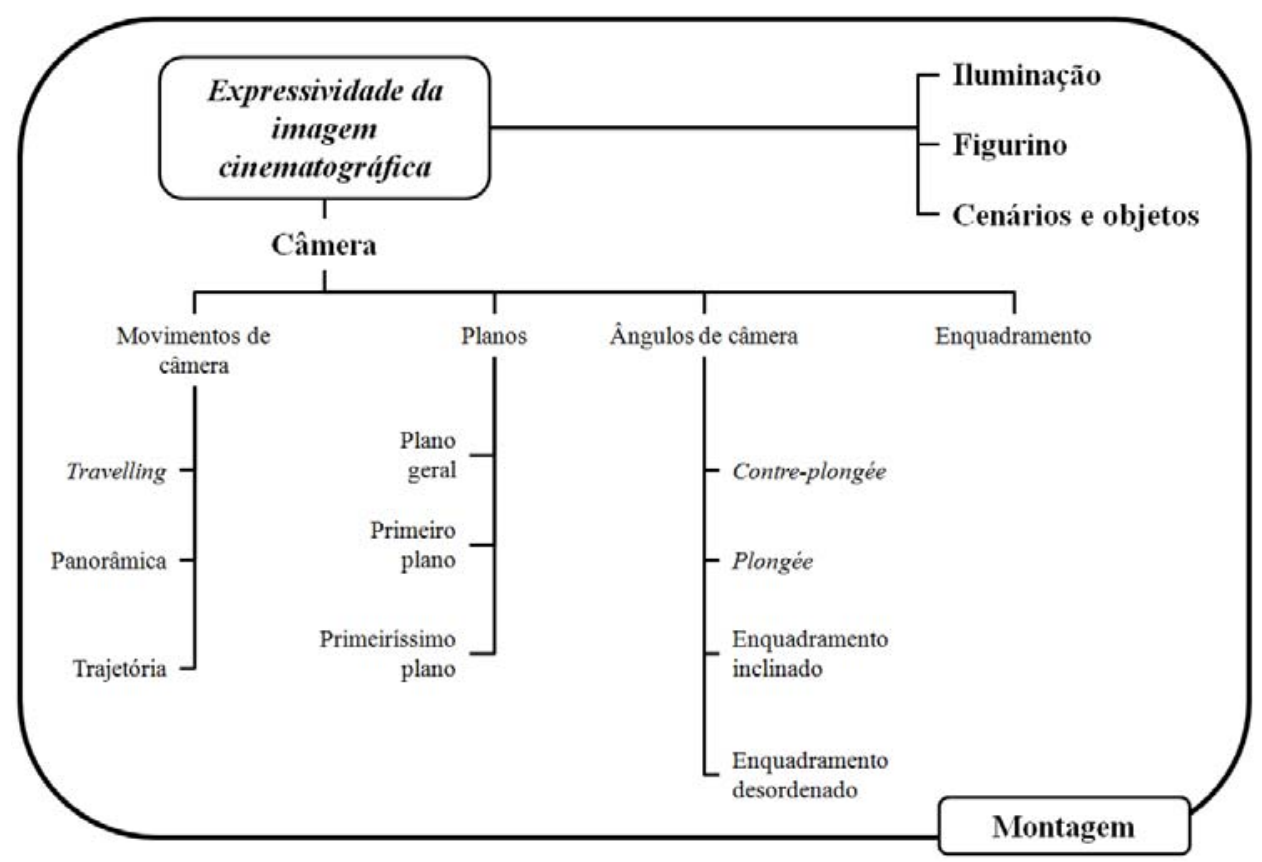

(Fonte: Própria)

Tendo em vista os recursos de linguagem destacados, devemos ter em mente que o sentido assumido por determinada técnica cinematográfica, sejam os movimentos de câmera, seus ângulos, enquadramentos, metáforas, símbolos, montagem, etc...não são definitivos, constituindo em uma regra fechada, e sim em sentidos que se consolidaram com o uso atribuído pelos idealizadores das películas ao longo da história do cinema. A liberdade criativa e expressiva faz-se importante, por meio da experimentação de novos recursos e linguagens.

Ou seja, os sentidos assumidos por dados elementos da linguagem cinematográfica se dão com a sedimentação do seu uso. Estas convenções culturais só se dão com a aceitação do público e isto depende dos padrões culturais, valores, costumes e normas sociais em que se encontram espectadores e filmes. Portanto, os sentidos se constroem a partir desse contexto cultural e o olhar do espectador nunca é neutro e vazio de significados.

Estando as diferentes significações de um filme associada aos diferentes modos de ver de um grupo social, se faz pertinente discutir sobre o "ensinar a ver" um filme, isso leva a valorização do consumo de filmes, incentivo a debates do que é visto e estimular confrontos entre diferentes interpretações. Esta dinâmica se faz extremamente pertinente dentro do ambiente escolar. Cabe lembrar a importância de incentivar a diversidade de olhares e interpretações dos indivíduos, considerando os diferentes contextos culturais que se pode encontrar. Relembramos aqui do conceito de cultura primeira de Snyders, valoriza-la e criar meios de emancipá-la a cultura elaborada ou escolar é função do papel mediador do professor.

A jornada de desbravamento do mundo da linguagem cinematográfica é um caminho sem volta. O espectador adquire um olhar que o acompanhará em qualquer obra que assista, ampliando sua experiência fílmica com uma percepção 
mais crítica do cinema, indo além do mero espectador. Lopes sintetiza bem: "Aprender a ver cinema é realizar esse rito de passagem do espectador passivo para o espectador crítico" (LOPES, 2013, p. 7).

Sendo a Escola um espaço onde o cinema tem se feito tão presente desde sua origem, torna-se importante que a linguagem cinematográfica contribua com o processo educativo. A introdução da linguagem do cinema no ambiente escolar potencializa a aquisição de conhecimento e desenvolve o juízo crítico. Lopes denomina este processo como "alfabetização cinematográfica" (ibidem, 2013, p. 8). E é esse processo de alfabetização, por meio do conhecimento da linguagem do cinema e da mediação do professor que defendemos nesta proposta teórica.

\section{DIÁLOGOS ENTRE MEDIAÇÃO SEMIÓTICA E A TEORIA DE CINEMA DE MARCEL MARTIN}

Durante o processo de sistematização e emancipação de cultura primeira em cultura elaborada, o professor exerce seu papel mediador. Isto não se faz diferente com o uso do cinema como ferramenta pedagógica em sala de aula.

Baseando-se no conceito de mediação semiótica, onde temos uma relação estímulo resposta ( $S \rightarrow R$ ), o filme enquanto dado físico constitui um estímulo ao espectador (estudante). No entanto, temos um terceiro elemento nesta relação, que se dá pela figura do professor, agindo como mediador do processo. Esta mediação se dá desde a escolha do filme (ou fragmento deste), passando pela definição de um roteiro de atividade, até apontamentos feitos pelo professor durante a exibição. Nesse último caso, o conhecimento da linguagem cinematográfica pelo professor se faz pertinente, uma vez que este pode evidenciar aos estudantes uma série de sentidos até então inacessíveis.

A tensão estabelecida entre estudante e filme se dá de modo dialético, onde seu repertório cultural (cultura primeira/contexto mental) operará um constante diálogo com o contexto fílmico da obra, bem como o conjunto de conhecimentos que se pretende sistematizar (cultura elaborada). $O$ resultado é um conjunto de novos sentidos que emergem da obra, configurando em uma nova experiência cinematográfica.

Abaixo, na Figura 2, buscamos resumir de maneira gráfica a dinâmica proposta por este conjunto de aportes teóricos.

Figura 2. Resumo gráfico do aporte teórico proposto. 


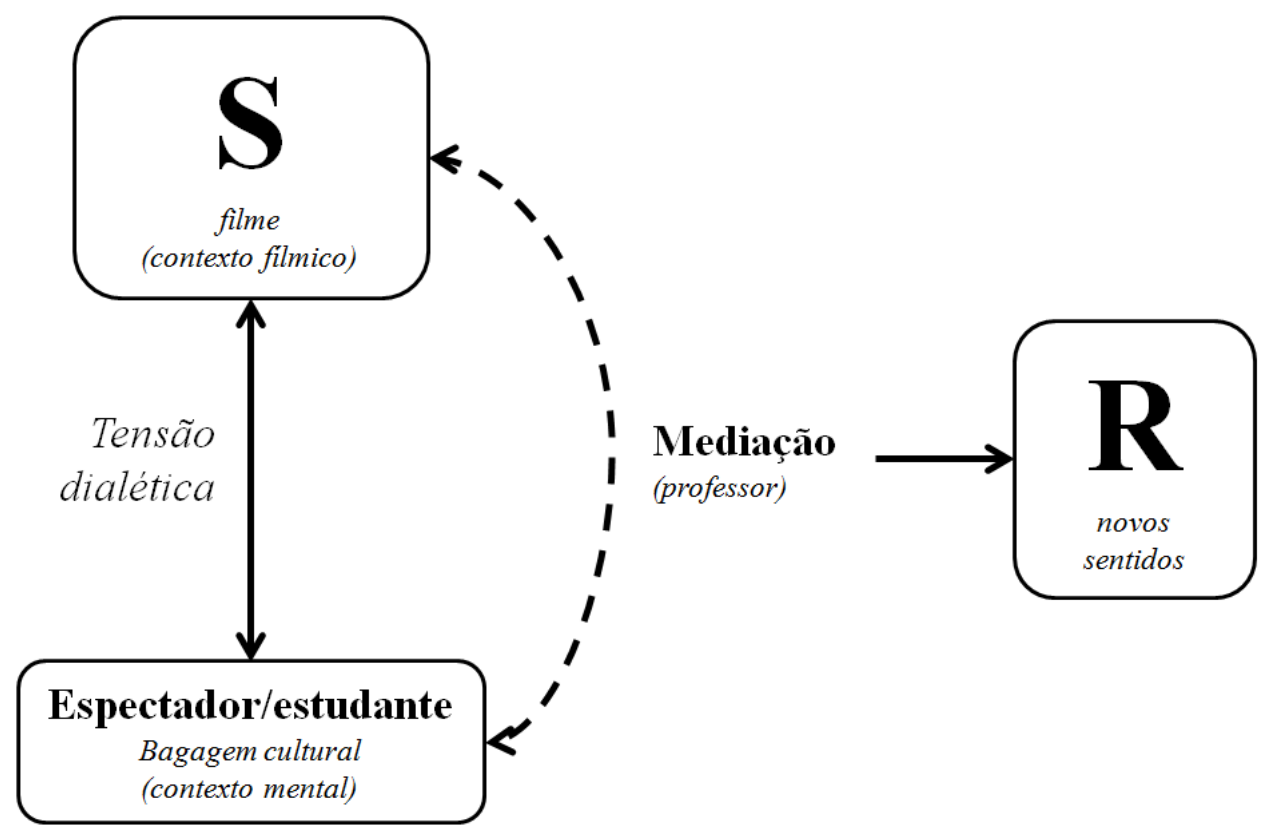

(Fonte: Própria)

\section{CONSIDERAÇÕES FINAIS}

Percebemos que o professor pode tomar os vínculos entre imagens de maneira própria e pessoal, conjurado aos objetivos intencionais de sua prática docente, o que constitui a sua prática mediadora. O sistema de signos da linguagem está no coração de todas as formas de educação, seja na aprendizagem informal, no ensino que ocorre em atividades diárias da comunidade de origem, ou nas atividades formalmente organizadas através do currículo que é promulgada em sala de aula. Enfim, o que desejamos aqui é proferir uma defesa sobre as potencialidades do filme, como uma verdadeira "floresta de signos" aguardando ser percebida e interpretada aos objetivos educacionais pela mão do professor.

Nosso trabalho concebe essas relações a partir da linguagem cinematográfica de Marcel Martin, que também nos oferece a possibilidade para um amplo diálogo com a mediação semiótica de Vigotski. Defendemos que essa tomada de posição reforça o caráter da imagem em estabelecer uma intensa relação dialética com o espectador, partindo de suas expressões afetivas e intelectuais, de modo a construir significado. Deste modo, o espectador não é um mero receptor passivo da atividade criadora do realizador do filme. Muito além, o espectador assume importância crucial ao ser o indivíduo que mergulhará em maior ou menor profundidade nas diversas camadas da obra, delimitando um sentido ao fragmento da realidade capturado pela câmera e proposto pelo autor. Esses sentidos dependerão sobre tudo do alinhamento entre a obra cinematográfica, a mediação do professor e o repertório cultural dos estudantes. O que confere uma singularidade para cada atividade realizada, dada a natureza heterogênea de uma sala de aula. como estes permite a utilização do cinema em sala de aula que vai além do "ver" 
o filme na escola. Confere a oportunidade das ciências escolares dialogarem com o repertório cultural de nossos estudantes, estreitando os laços da cultura popular e a cultura escolar. De modo específico com o ensino de ciências, temos a oportunidade de tratarmos de uma Ciência mais humana, menos dura e conteudista, oferecendo aos nossos estudantes a possibilidade de refletirem, discutirem e criticarem as manifestações culturais da ciência, desconstruindo mitos e fortalecendo uma visão crítica desta. 


\title{
THEORETICAL REFLECTIONS ON SCIENCE AND CINEMA TEACHING: POSSIBLE APPROACHES TO CINEMATOGRAPHIC LANGUAGE
}

\begin{abstract}
The film can be a tool with potential promotion of student's culture in school culture. The teacher acquires is a key piece, assuming mediator. However this lack appropriate to-be film making as an artistic expression and technique, carrying a peculiar language. In particularly science education, there are a lack with knowledge of cinema. Our intentions reside in a set approach with this theoretical framework, especially the cinematographic language of Marcel Martin that assumes a dialectic tension between spectator and footage. We find this concept with confluence theory of Vygotsky's semiotic mediation, allowing dialogues between them. This theoretical approach points to ways little explored by Research Science Teaching, enabling a classroom discussion at a science but human and less lasting.
\end{abstract}

KEY-WORDS: Science education. Cinema. Film language. Semiotic mediation. Vygotsky. 


\section{REFERÊNCIAS}

ANGELL, H. E. Teaching films. Educational Screen, n. 8, 1929.

CARRERA, V. M. Contribuições do uso do cinema para o ensino de ciências tendências entre 1997 e 2009. 2012. 125 p. Dissertação (Mestrado em Educação) - Faculdade de Educação, Universidade de São Paulo, São Paulo. Disponível em: < http://www.teses.usp.br/teses/disponiveis/48/48134/tde-29052012-133206/ptbr.php>. Acesso em: 24 jun. 2017.

CARRIÈRE, J.-C. A linguagem secreta do cinema. Ed. Especial. Rio de Janeiro: Nova Fronteira, 2014. 205 p.

CARVALHO, R. M. B. D. Georges Snyders: em busca da alegria na escola. Perspectiva, Florianópolis, v. 17, n. 32, p. 151-170, jul/dez. 1999. Disponível em: <https://periodicos.ufsc.br/index.php/perspectiva/article/viewFile/10528/10074 >. Acesso em: 24 jun. 2017.

CHRISTOFOLETTI, R. Filmes na sala de aula: recurso didático, abordagem pedagógica ou recreação? Santa Maria Revista Educação, Santa Maria, v. 34, n. 3, p. 603-616, set./dez. 2009. Disponível em: $<$ https://periodicos.ufsm.br/reveducacao/article/view/871>. Acesso em: 24 jun. 2017.

COSTA, F. C. O primeiro cinema - Espetáculo, narração, domesticação. 1a Edição. São Paulo: Scritta, 1995. 193 p.

CUNHA, M. B. D.; GIORDAN, M. A imagem da ciência no cinema. Química Nova na Escola, v. 31, n. 1, p. 9-17, 2009. Disponível em:

<http://qnesc.sbq.org.br/online/qnesc31_1/03-QS-1508.pdf>. Acesso em: 24 jun. 2017.

DRANSFIELD, J. E. A technique for use of motion pictures in schools. Educational Screen, n. 7, 1927.

DUARTE, R. Cinema \& Educação. 3a Edição. Belo Horizonte: Autêntica Editora, 2009. $103 \mathrm{p}$.

FIGUEIREDO, B. G.; SILVEIRA, A. J. T. História da Ciência no Cinema 3. 1a Edição. Belo Horizonte: Argvmentvm, 2010. 254 p. 
$<$ http://www.periodicos.udesc.br/index.php/linhas/article/view/1276>. Acesso em: 24 jun. 2017.

KOSMINSKY, L.; GIORDAN, M. Visões de ciências e sobre cientista em sala de aula entre estudantes do ensino médio. Química Nova na Escola, n. 15, p. 11-18, maio 2002. Disponível em: <http://qnesc.sbq.org.br/online/qnesc15/v15a03.pdf>. Acesso em: 24 jun. 2017.

LEONT'EV, A. N. The Problem of Activity in Psychology In: WERTSCH, J. V. (Ed.). The Concept of Activity in Soviet Psychology: Routledge, 1981. p.37-71.

LOPES, J. D. S. M. Cinema e educação: o diálogo de duas artes. SCIAS Arte/Educação, n. 1, v. 1, p. 2-14, 2013. Disponível em: <revista.uemg.br/index.php/SCIAS/article/download/405/276>. Acesso em: 24 jun. 2017.

MARTIN, M. A Linguagem Cinematográfica. 1a Edição. Belo Horizonte: Editora Itatiaia, 1963. 222 p.

NAPOLITANO, M. Como usar o cinema na sala de aula. 5ạ Edição. São Paulo: Editora Contexto, 2013, 251 p.

OLIVEIRA, B. J. D. História da Ciência no Cinema. 1a Edição. Belo Horizonte: Argvmentvm, 2005. $189 \mathrm{p}$.

História da Ciência no Cinema 2 - O Retorno. 1a reimpressão. Belo Horizonte: ARGVMENTVM, 2009. 158 p.

Ciência e Cinema na Sala de Aula. Belo Horizonte: Fino Traço Editora, 2012. 167 p.

PIASSI, L. P. D. C. Interfaces didáticas entre Cinema e Ciência - Um estudo a partir de 2001: uma odisseia no espaço. 1a Edição. São Paulo: Editora Livraria da Física, 2013, $267 \mathrm{p}$.

PINO, A. Semiótica e cognição na perspectiva histórico-cultural. Temas em Psicologia, Ribeirão Preto, v. 3, n.2, p. 31-40, 1995. Disponível em: $<$ http://pepsic.bvsalud.org/scielo.php?script=sci_arttext\&pid=S1413389X1995000200005>. Acesso em: 24 jun. 2017. 
em Ciências. Revista Brasileira de Pesquisa em Educação em Ciências, v. 11, n. 2, p. 183-204, 2011. Disponível em:

<https://seer.ufmg.br/index.php/rbpec/article/viewFile/2406/1806>. Acesso em: 24 jun. 2017.

SNYDERS, Georges. A alegria na escola. São Paulo: Manole, 1988.

TERCEÑO, J. R. El cine en la realidad de las aulas. Historia y Comunicación Social, v. 19, n. especial, p. 565-574, março 2014. Disponível em: <http://revistas.ucm.es/index.php/HICS/article/view/45161>. Acesso em: 24 jun. 2017.

VIGOTSKI, L. S. A Formação Social da Mente. 7a Edição.São Paulo: Martins Fontes, 2007, 182 p.

WERTSCH, J. V. The Concept of Activity in Soviet Psychology: An Introdution. In: WERTSCH, J. V. (Ed.). The Concept of Activity in Soviet Psychology: Routledge, 1981. p. 3-36.

Recebido: 2017-01-10

Aprovado: 2017-08-06

DOI: 10.3895/rbect.v10n3.5297

Como citar:

MELLO, R. V. M.; ARAUJO NETO, W. N. Reflexões teóricas sobre Ensino de Ciências e Cinema: aproximações possíveis com a linguagem cinematográfica. Revista Brasileira de Ensino de Ciência e Tecnologia, v. 10,

n. 3, 2017. Disponível em: <https://revistas.utfpr.edu.br/rbect/article/view/5297>. Acesso em: xxx. Correspondência:

Rodrigo Vasconcelos Machado de Mello - rodrigo-vmm@hotmail.com

Direito autoral: Este artigo está licenciado sob os termos da Licença Creative Commons-Atribuição 4.0 Internacional. 